\title{
GROWTH OF E -COMMERCE, STRATEGY ADOPTED AND CONSUMER BEHAVIOUR TO \\ IT
}

\author{
Devendra Verma \\ M.com- BVIMR NEW DELHI \\ New Delhi (India)
}

\begin{abstract}
In the current scenario E-Commerce increases day by day with a high growth rate. The growth of $e$ commerce comes from various challenges faced by it. ECommerce play important role in economic growth. In modern business E-Commerce is lifeline for business or also refers as WBC for any organization to grow globally. India is becoming a better market for the ecommerce sector. The rise in internet literacy has led to an influx of investment in e-commerce firms. The service provided online the internet network. Various transaction of money, funds are considered as Ecommerce. These business transactions can be done in four ways: Business to Business (B2B), Business to Customer (B2C) and Customer to customer (C2C), Customer to Business (C2B). The best definition of E-Commerce is a commercial transaction which is done over the internet.
\end{abstract}

Keywords-E-COMMERCE, ONLINE TRANSACTION, $\mathrm{B} 2 \mathrm{~B}, \mathrm{~B} 2 \mathrm{C}, \mathrm{C} 2 \mathrm{~B}, \mathrm{C2C}$

\section{INTRODUCTION}

E-Commerce is new methodology of modern business which critically explain the needs and wants of customer of an organization. Thus helpful in cost reduction and improve delivery speed. E-Commerce refers to exchange of business information using:

1-Electronic Data Exchange

2-Electronic Mails

3-Electronic Fund Transfer

4-Other Network Based Technologies.

E-Commerce is trading in goods and services using networks. According to Internet and Mobile Association of India- the ECommerce industry reached 211005 crore in 2016.

According to Google India Research- By 2021 India is expected to generate $\$ 100$ billion from online retail, out of which $\$ 35$ billion through E-commerce.

\section{MODELS OF E-COMMERCE}

1-B2B (BUSINESS TO BUSINESS):- In these both are business organization in simply it means trading between two organizations. Example-alibaba.com, hellotrade.com
2-B2C (BUSINESS TO CUSTOMER): In this trading takes place between businesses to customer. Example- amazon.com, flipkart.com

3 C2B (CUSTOMER TO BUSINESS):- In this customer sell his product to business organization. Example- freelancer.com 4 C2C (CUSTOMER TO CUSTOMER) : In this trading took place between customer to customer. Examplequicker.com, olx.com

5 C2G (CUSTOMER TO GOVERNMENT) : In this area cover such as Election, Votes, Tax etc Examplewww.whitehouse.gov (exchange information)

6 G2B (GOVERNENT TO BUSINESS) : In this government sell information to business. Exampleincometaxindia.gov

7 G2C (GOVERNMENT TO CUSTOMER) : In this government provide information to consumer electronically. Example- IRCTC, download or apply forms

\section{Consumer Behavior}

Consumer behavior is the study of individuals nature, groups and organizations behavior and the processes how they use to select, secure, and dispose of products and services, to satisfy their needs and wants. The study of consumer behavior helps to understand the past and also predict the future. (Wikipedia)

\section{LITERATURE REVIEW:}

In order to analysis E-commerce many study was undertaken. The study help to analysis the growth of E-Commerce, factor influences E-Commerce and Challenges faced by ECommerce

Studies Related To E-Commerce and Consumer Behaviour :

Nisha Gupta and Rajiv Jain (2017) in their study titled "Consumer Behavior towards E- Commerce: Online Shopping" identified that there are major security concerns in online transactions and at present people do not feel comfortable doing the shopping online. They feel that there are high risks of fraud and hoax in online business. 
Niranjanmurthy $M$ et.al, (2013 ) Analyzed ecommerce and m-commerce and expressed that, Ecommerce is widely considered the buying and selling of products over the internet, but any transaction that is completely through electronic can be considered ecommerce. These days, m-commerce is playing a major role in online retail marketing and people are using this technology increasing all over the world. Mobile commerce involves electronic transactions by the use of mobile phone. They mentioned various advantages, limitations and growth drivers of $\mathrm{m}$ commerce.

Liberman and Stashevsky, (2002), Park and Kim, (2003) Show that the major concerns of online shopping are security of online payments" and privacy of personal information".

According To Forrester: The E-Commerce market in India set to grow fastest within Asia-Pacific-Region. INDIA RETIAL MARKET:

$\$ 470$ billion estimated in 2011

$\$ 675$ billion estimated in 2016

\$850billion estimated by 2020 .

\section{DISTINGUISH BETWEEN TRADITIONAL COMMERCE AND E-COMMERCE:}

1. In traditional commerce heavy dependency on information exchange from one person to another while in e commerce information exchange through electronic communication channel.

2. It is difficult to established and maintain standard practices in traditional commerce but in e commerce a uniform strategy can be easily established.

3. In tradit5ional business there is unavailability of a uniform platform for buyer and customer. Whereas e commerce websites provides the customer and buyer various cost effective platform.

4. In e commerce advertisement take a great place for its success, A proper advertisement established with great influence while in traditional business advertisement is less effective and very costly.

5. In e commerce we get various facility like shop from home, comparison of product, saving of time etc. while is traditional commerce we get physical tasting of product, bargaining and satisfaction on the spot.

\section{OBJECTIVE OF STUDIES:}

1. To analyze the various factors influencing the behavior of the consumers towards electronic Commerce.

2. To find out the impact of electronic marketing tools in determining the buying behavior of consumers.

3. To know the consumers awareness about E -
Commerce.

4. To identify the barriers faced in electronic commerce growth

\section{FACTOR DRIVING E COMMERCE GROWTH}

1. Internet content in local languages- this factor helps a lot to growth of e commerce. In a move to grab the opportunity e commerce companies launch their apps with many local languages which help the customer to shop from their comfort zone.

Growth in non metro cities- customer of e commerce increases day by day even in small cities. This can be a important factor that determined the growth of $\mathrm{e}$ commerce.

Mobile commerce - rise in smart phone usage have a great influence in growth of e commerce.

Cashless transactions- a gradually increase in e banking among people reflect that people getting comfortable with using e banking tool for their commerce activities. Many online retails insist customer to use debit/credit cards, e wallets for transaction, this is how ever a welcome change.

\section{FACTOR AFFECTING ONLINE CONSUMER BEHAVIOUR}

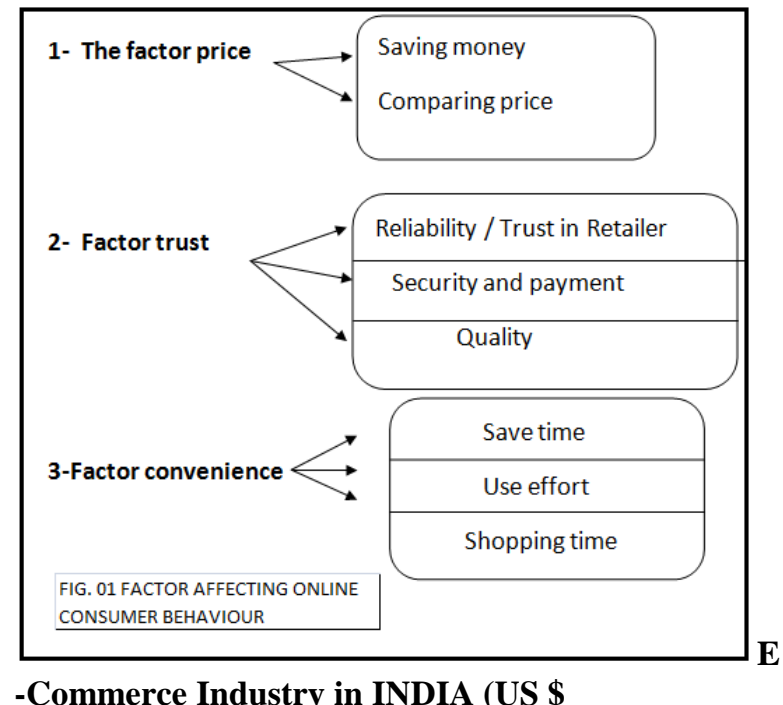

-Commerce Industry in INDIA (US \$ 


\section{Billions)}

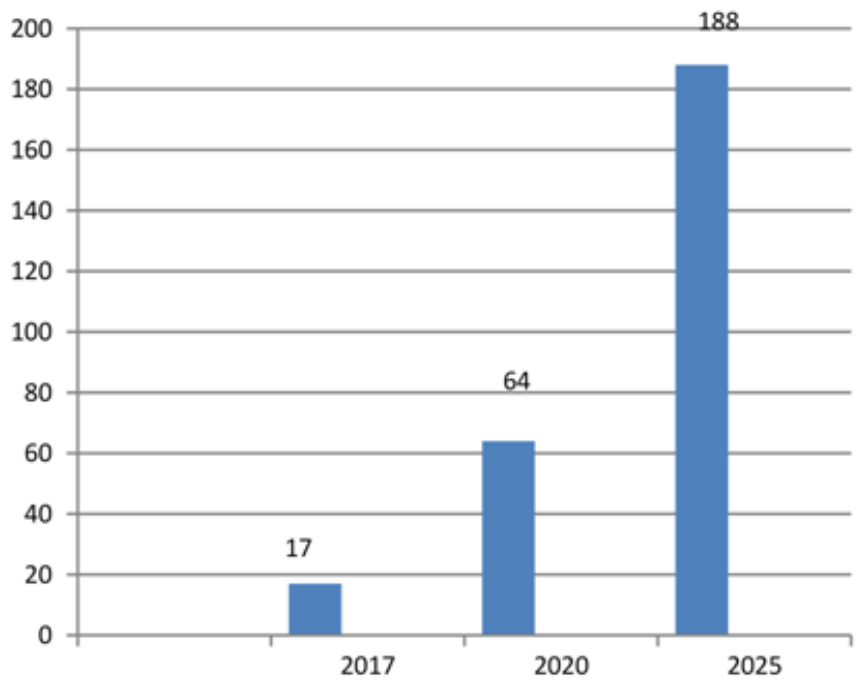

Source: - Economic Times, PWC Express

IV. STRATEGIES ADOPTED:

- Expansion- e commerce companies or gradually expanding to different cities, region and even countries. They also expand their product and launch a variety of product.

- Ancillary services- e commerce companies launches various ancillary services with their core product and services like:

1. Amazon India launch one day delivery

Guarantee on a purchase for a nominal charge flip kart do same.

2. E-commerce websites are also launches various e wallets services.

- Personalized experience- many e commerce websites provides personalized experiences to customer to cater to their needs and interest, depending upon their location, choices etc. This strategy has helped e-commerce companies to know the customer's demand better and serve them accordingly.

- Subscription for e commerce- e commerce companies also adopting subscription modal to provides extra benefits to their customer which suits their needs.

Example- Amazon prime, Flip kart-First.

\section{GOVERNMENT INITIATIVES IN E- COMMERCE}

- The ministry of electronics and information technology (IT) issued the draft rules for digital payments for public consultation, which aim to address the issues of consumer interest and security concerns.
- Government announced the launch of BHIM app. It will help increase digital payments in the country. BHIM app has been adopted by 12.5 million so far. The government will launch new schemes to promote the usage of BHIM; these are referral bonus scheme and a cash back scheme.

- Under the digital India movement, government launched various initiatives like udaan, Umang, startup India portal etc..

- In order to increase the participation of foreign players in the e-commerce field, the Indian government hiked the limit of foreign direct investment (FDI) in the e-commerce marketplace modal for up to 100 per cent (in B2B models).

- The government of India has distributed rewards worth around Rs 153.5 crore (US\$ 23.8 million) to 1 million customers for embracing digital payment, under the lucky grahak yojana and digi-dhan vyapar yojana.

Source: union budget 2017-18, media sources, aranca research

\section{CONCLUSION}

From the study many conclusion are derived in which merit and demerit e commerce also concluded. The growth of e commerce with high percentage is symbolism of great change in attitude of consumer towards e commerce. Many steps taken by government to encourage e commerce industry in rural area and also in urban area.

Business line stated that mobile wallets are main reason for growth of e commerce sector. In business line article it stated that mobile transaction has increases from 200 billion in FY16 TO 3000 billion in FY18. The growing demand in India made e commerce fastest growing sector in Asia Pacific region. In India there are so many barriers available but this are reducing day by day and the young generation had already accepted the model of in their daily routine life.

\section{REFERENCE}

1) C Nwaizugbo, I. and D, Ifeanyichukwu C. (2016). Understanding Consumers' Behaviour towards Online Shopping: A Study of Online Shoppers in Anambra State. International Journal of Sales Vol. 5 No. 2.

2) Kumar, M. (2016). Consumer Behavior and Satisfaction in E-Commerce: A Comparative Study Based On Online Shopping Of Some Electronic Gadgets. International Journal of Research in Commerce \& Management Vol. 7 No. 07 (July) ISSN 0976-2183.

3) Kinker, M. \& Shukla, N.K. (2016).An Analysis of Consumer Behaviors towards Online Shopping of 


\section{International Journal of Engineering Applied Sciences and Technology, 2019 \\ Vol. 4, Issue 4, ISSN No. 2455-2143, Pages 179-182 \\ Published Online August 2019 in IJEAST (http://www.ijeast.com)}

Electronic Goods With special reference to Bhopal and Jabalpur city. International Journal of Innovation and Applied Studies ISSN 2028-9324 Vol. 14 No. 1 Jan, pp. 218-235

4) Hooda, S. \& Aggarwal, S. (2012).Consumer Behaviour Towards E-Marketin. International Refereed Research Journal Vol. III, Issue 2(2), April.E-ISSN 2229-4686.

5) Gunasekaran, A., et al. "E-commerce and its impact on operations management." International journal of production economics 75.1 (2002): 185-197.

6) Subramani, Mani, and Eric Walden. "The impact of e-commerce announcements on the market value of firms." Information Systems Research 12.2 (2001): 135-154.

7) Eastin, Matthew S. "Diffusion of e-commerce: an analysis of the adoption of four ecommerce activities." Telematics and informatics 19.3 (2002): 251-267.

8) Drew, Stephen. "Strategic uses of e-commerce by SMEs in the east of England." European Management Journal 21.1 (2003): 79-88.

9) Wong, Poh-Kam. "Global and national factors affecting e-commerce diffusion in Singapore." The Information Society 19.1 (2003): 19-32.

10) Schafer, J. Ben, Joseph A. Konstan, and John Riedl. "E-commerce recommendation applications." Applications of Data Mining to Electronic Commerce. Springer US, 2001. 115-153.

11) Daniel, Elizabeth, and Hugh Wilson. "Adoption intentions and benefits realized: a study of e-commerce in UK SMEs." Journal of Small Business and Enterprise Development 9.4 (2002): 331-348.

12) Clayton, T. et al (2002). Electronic Commerce and Business Change.

13) Bairagi, A. K. (2011). "Utilization of E-Commerce can Change the Auction Culture of Bangladesh Specially in Public Sector". IJCIT, Vol. 2(1), pp. 5561.

14) Almeida, G. A. A. et al (2007). Promoting ECommerce in Developing Countries. www.diplomacy.edu. 